\title{
The Effect of Project Based Learning and Learner Autonomy on Students' Speaking Skills
}

\author{
Mirah Setia Dewi, N.K ${ }^{1 *}$, Marhaeni, A.A.I.N2, Ramendra, D.P3
}

${ }^{123}$ Universitas Pendidikan Ganesha

A R T I C L E I N F O

Article history:

Received 18 May 2019

Received in revised

form

29 June 2019

Accepted 28 July 2019

Available online 30

August 2019

Keywords:

Learner Autonomy,

Project-based Learning,

Speaking Skills

\section{A B S T R A C T}

This study was aimed at investigating the effect of project-based learning on students' speaking skills at the eighth grade students of SMPN 5 Kuta Selatan in academic year 2018/2019. The design of the study was post-test only control group with $2 \times 2$ factorial designs. Sample involved 82 students that were selected through random sampling technique. The data were collected through questionnaire of learner autonomy and speaking performance test which had been validated before. The data were analysed by using two way ANOVA and t-Scheffe. The study discovered: there was different effect in speaking skills between the students who were taught by using project-based learning and those who were taught by using conventional method $(F=18.391$ and $p<0.05)$ in which the Project-Based Learning group excelled better in speaking skills, there was an interaction between learner autonomy and project-based learning in affecting students' speaking skills $(F=45.325$ and $p<0.05)$, the students in which high learner autonomy who were taught by using the project-based learning affect better than those who were taught by using conventional method; however, there was not significantly different in speaking skills of the students with low learner autonomy who were taught by using projectbased learning and who were taught by using conventional method $(p>0.05)$. 


\section{Introduction}

Responding to the phenomenon of changes in labour requirements and progress, schools need to be prepared to face the challenges of the 21st century. Understanding of the 21st century is important to be conveyed to students. Achievement of 21st century skills is done by understanding the characteristics, achievement techniques and learning method undertaken. On the present learning in schools is still more focused on learning outcomes in the form of mere knowledge. It is only to the level of memory (C1) and understanding (C2) and has not touched many aspects of the application (C3), analysis (C4), synthesis (C5), and evaluation (C6). The research which was conducted by Pratiwi (2015) showed most of the activities in school are including to remembering; however, only few activities supposed students to use and implement their knowledge and relate to analysing level. This means that in general, learning in schools has not invited students to apply, process each of the elements of the concept being studied to make (synthesis) generalization, and have not invited students to evaluate (think critically) on the concepts and principles they have learned. Meanwhile, aspects of skills (psychomotor) and attitude (attitude) are also neglected.

Education in Indonesia is using Curriculum 2013 which has been supported by the government, which is based on the character and competence that requires children to be active in learning and mastering four language skills, namely listening, speaking, reading, and writing, which are interconnected to each other in language learning. Those are very important when learning English because those are related to each other. Listening is the first language which is to give attention to the ears for the purpose of the hearing. Reading is the act of getting information from texts. Speaking is the act of giving a speech or talk. Speaking is one of the most important skills for the students and they should master it in order to make them speak well with others and the listeners can understand well what the speaker says. Pratiwi (2016) states that speaking becomes the skill which must be highlighted in teaching English as a foreign language, because it is a productive skill when the teacher can see students occupying the target language actively for real communication.

According to Brown (2004) speaking is an interactive process of constructing meaning that involves producing, receiving, and processing information. When speaking, the people be able to make meaning depends on the context of the information occur and consider some circumstances. In the educational setting, speaking and writing activities, the students are given the opportunity to experience with the target language. They are encouraged to express meaning by saying something which may affect someone else's point of view or taught (Clark \& Clark, 1997). Artini (2017) states that language learners are considered successful language speakers when they can perform communicative function appropriately in various situation. According to Thornbury (2005) speaking is so much a part of daily life that speakers take it for granted. It means that speaking is such an activity that takes any part of daily life when doing communication with others. He also states that there are some things which are involved in speaking; the first point to reemphasize is that speech production takes place in real time and is therefore essentially linear. Words follow words, and phrases follow phrases; speech is produced utterance by utterance, in the response of the word by word and utterance, by utterance productions of the person that speakers are talking to. In other words, speaking is a speech which is produced utterance by utterance that may be responding from the word by word and utterance by the utterance. For example, when a person speaks something to others, the others will listen, then also a response by using words in oral form. (Richards, 2008) claims that the mastery of speaking skills in English is a priority for many secondlanguage or foreign-language learners. Consequently, learners often evaluate their success in language learning as well as the effectiveness of their English course on the basis of how much they feel they have improved in their spoken language proficiency.

Generally, from a variety of research findings show that speaking is difficult. The research which was conducted by Heriansyah (2012) and Taiqin (1995) show that the frequent difficulties in speaking such as the students often have no ideas about what to say, the students are also shy and uncomfortable as well as not confident if they make mistakes, the students are afraid of making errors in class and they are not used to talking in the class since their pronunciation and vocabulary are poor and confined. These statements are supported by Zhang (2009) that speaking remains the most difficult skill to master for the majority of English Learners, and they are still incompetent in communicating orally in English. There are some factors that cause difficulty in speaking such as inhibition (students are worried about making mistakes, fearful or criticism, or simply shy), nothing to say (students have no motive to express themselves), low or uneven participation (only one participant can talk at a time because of large classes and the tendency of some learners to dominate, while others speak very little or not at all), mother-tongue use (learners who share to same mother tongue tend to use it because it is easier and because learners feel less exposed if they are speaking their mother-tongue) Ur (1996). Project-Based Learning (PjBL) is 
one of the learning methods that can train skills and achieve the 2013 curriculum goals in facing the challenges of the 21st century.

Bell (2010) stated that PjBL is an innovative method of learning that teaches a multitude of strategies critical for success in the twenty-first century. Students drive their own learning through inquiry, as well as work collaboratively to research and create projects that reflect their knowledge. Moreover, Larmer, Mergendoller, \& Boss (2015) state that PjBL provides opportunities for students to build qualities, as well as more deeply learn conventional academic content and understand how it applies to the real world. They also claim that PjBL, is a powerful teaching method that can motivate students, prepares students for college, careers, and citizenship, helps students meet standards and do well on tests that ask students to demonstrate in-depth knowledge and thinking skills, allows teachers to teach in a more satisfying way, provides schools and districts with new ways to communicate and to connect with parents, communities, and the wider world. PjBL is an effective approach which allows multiple skills to be developed through integrated and meaningful activities.

The PjBL is one of the learning methods that can be used by the teacher so that the teacher automatically also using a scientific approach (scientific approach) in learning. A scientific approach is a learning approach where students acquire knowledge based on scientific work methods. Empirically, Rochmahwati, (2015) conducted a study about the implementation of Project-Based Learning to raise students' speaking skill. The result of the study showed that PjBL is an effective approach that allows multiple skills to be developed through an integrated, meaningful activity. This type of learning is valuable since it is connected to real-world issues and enables learners to demonstrate their knowledge in practical ways. It also engages learners in sustained investigations and allows learners to participate in a variety of tasks that seek meaningful interactions. The students showed a significant positive attitude toward the implementation of PjBL in speaking class.

The success of PjBL implementation has been reported by Gaer which is cited from Rochmahwati (2015), who taught speaking skill to a population of Southeast Asian refugees who had been in their beginning-level ESOL (English for Speaker of Other Language) classes. The research showed that speaking skill is improved through PjBL. The research about PjBL is also done by Ismuwardani, Nuryatn, and Doyin (2018). Their study showed a significant increase in the implementation of Project-Based Learning to creativity divided into three points were fluency, flexibility, and originality. It is not easy to build the creativity of students in learning, especially learning English as Foreign Language. Research on the implementation of project-based learning also conducted by Chiang and Lee (2016) which was shown that Project-based learning there was a positive effect for students' learning, motivation, it encourages the vocational high school teachers that their students have the potential to enjoy in learning, their learning motivation can be stimulated and the trigger could be Project-based learning. Ravitz (2010) as cited in Chiang and Lee (2016) stated that project-based learning is used as 'project' as vehicles to encourage student motivation and to provide a means for demonstrating and explaining what they have learned.

Learner autonomy has been a major area of interest in a foreign language (FL) teaching for some 30 years. According to Little (1995) as cited in Ahmadzadeh (2014) learner autonomy has been defined as a capacity for action, independent learning and learners accepting responsibility for their learning and sharing in the decisions and initiatives that give shape and direction to the learning process. In other words, students take responsibility and participate fully in their learning and working in groups, between and together with other students and with the teacher. Through the autonomy of learning students reflect on their experiences and are competent to create their goals and objectives as well as the challenges of how to express ideas or theories that they obtain through independent experiences.

PjBL is rarely implemented in Bali, however; it should be implemented by teachers at school in order to achieve the goals of Curriculum 2013 in which facing the challenges of 21st Century. Referring to those descriptions, the researcher then concluded to conduct a study in order to know the effect of Project-Based Learning and Learner Autonomy on students speaking skill. Empirically, it is supported by some studies. A research which was conducted by Jamila (2013) about the use of learner autonomy in teaching speaking, the result of the study showed that learner autonomy is not yet fully executed to assume the principles of learner autonomy in English speaking classes at the tertiary level. Yuliani and Lengkanawati (2017) also done a research entitled Project-Based Learning in promoting Learner Autonomy in an EFL classroom, this study showed that the implementation of PjBL boosted students' learning outcomes and construct self-directed learning and the students autonomously engaged in the completion of the project in a more positive attitude. Based on those studies, it can be concluded that PjBL can increase students' autonomy and PjBL can affect learner autonomy. 


\section{Methods}

This research is an experimental study which was a systematic and scientific approach in which the researcher determined one or more variables. According to Cohen, et al (2007) there are several of the experimental design, one of them is factorial design with Post-test only control group design. In the factorial design, there may be two or more independent variables acting on the dependent variable. Here was the constellation of 2x2 factorial designs which is adopted from Cohen et.al (2007):

Table 1. The Design of the Study

\begin{tabular}{lll}
\hline \multicolumn{1}{c}{ Teaching } & Project-Based Learning (A1) & Conventional Method \\
Ltrategies & Experimental Group & (A2) \\
Learner Autonomy (B) & & Control Group \\
\hline High Learner Autonomy (B1) & A1B1 & A2B2 \\
Low Learner Autonomy (B2) & A1B2 & A2B2 \\
\hline
\end{tabular}

Remarks:

A1 : the students who are taught by using PjBL

A2 : the students who are taught by using conventional methods

B1 : the students who have high learner autonomy

B2 : the students who have low learner autonomy

A1B1 : the students who have high learner autonomy were taught by using PjBL

A2B1: the students who have high learner autonomy were taught by using conventional methods

A1B2 : the students who have low learner autonomy were taught by using PjBL

A2B2: the students who have low learner autonomy were taught by using conventional methods.

The population of this study was the eighth-grade students of SMPN 5 Kuta Selatan, which consisting of 340 students who are divided into 11 classes. This study used a random sampling method to get a sample from the population because this method efficient to be used in a big homogeneous population in order to give the same possibility for all the population members. The total sample of the study is 82 students, which were divided into some groups such as the A1B1 group which was consisted of 21 students, the A2B2 group which was consisted of 20 students, the A1B2 group which was consisted of 21 students, and the A2B2 group which was consisted of 20 students.

There were several instruments that are used in this study to gain data such as scoring rubric, test, and questionnaire. Speaking rubric was used to give score to the students' speaking test. The scoring rubric of speaking skills used was adopted from Brown (2004) which is consisted 5 criteria such as pronunciation, grammar, vocabulary, fluency, and comprehension. Speaking skill test was created to measure the degree of the students' speaking skills after implementing of PjBL. This post-test was a performance test in which both experimental and control group gave the same test. The learner autonomy questionnaire used a Likert scale.

The data are analysed by using Two Way ANOVA and t-Shaffee. Those are analysed after obtaining the scores from speaking skill post-test and learner autonomy questionnaire which was given to both experimental and control group.

\section{Result And Discussion}

Based on the descriptive analysis, the mean score of students who are taught by using PjBL was 3.82 , the mean score for the students who are taught by using conventional method was 3.49. The mean score for students who have high learner autonomy was 3.35 and 2.47 for the students who have low learner autonomy. The mean score for the students with high learner autonomy which are taught by using PjBL was 4.20 and 3.63 for the students with high autonomy who were taught by using conventional method. The mean score for the student with low learner autonomy who are taught by using PjBL was 3.45 and 3.35 for the students with low learner autonomy who are taught by using conventional method. It can be concluded that high learner autonomy can affect the result of students' achievement which were taught by using PjBL. 
1. There is different effect in speaking skills between students who were taught by using PjBL and those who are taught by using conventional method

Table 2. Different effect in speaking between PjBL and Conventional Method

\begin{tabular}{lrrrrr}
\hline \multicolumn{7}{c}{ One-Way ANOVA } & & \\
\hline & Sum of Squares & Df & Mean Square & F & Sig. \\
Between Groups & 8.457 & 3 & 2.819 & 18.391 & .000 \\
Within Groups & 11.956 & 78 & .153 & & \\
Total & 20.414 & 81 & & & \\
\hline
\end{tabular}

Based on the results of the One way ANOVA test (Table 2), it can be seen that the significance value (Sig.) was 0.000 which was smaller than the value $0.05(\mathrm{~F}=18.391$ and $\mathrm{p}<0.05)$. Thus, H0 was rejected, which meant that speaking skills of students who were taught by using PjBL were not the same as speaking skills of students who were taught by using conventional method. It can be concluded that there is difference effect in speaking skills between students who were taught by using PjBL and those who were taught by using conventional method.

2. There is an interactional effect between the implementation of PjBL and learner autonomy on students' speaking skills.

Table 3. Interact Effect between PjBL and Learner Autonomy

\begin{tabular}{lrrrrr}
\hline \multicolumn{7}{c}{ Two Way ANOVA } & & \\
\hline Source & Type III Sum of Squares & df & Mean Square & F & \multicolumn{1}{c}{ Sig. } \\
TS & $25.544^{\mathrm{a}}$ & 3 & 8.515 & 32.669 & .000 \\
LA & 1768.450 & 1 & 1768.450 & 6785.246 & .000 \\
& .000 & 0 & & & \\
TS*LA & 23.626 & 2 & 11.813 & 45.325 & .000 \\
Error & 41.701 & 160 & .261 & & \\
Total & 1839.591 & 164 & & & \\
a. R Squared $=.380$ (Adjusted R Squared $=.368$ ) & & & \\
\hline
\end{tabular}

Based on the results of the Two Way ANOVA (table 3), it can be seen that the interaction was significant, it is indicated by the interaction treatment significance value (TS * LA) of 0.000 which was lower than $0.05(\mathrm{~F}=45.325$ and $\mathrm{p}<0.05)$. Thus, $\mathrm{H}_{0}$ was rejected and $\mathrm{H} 1$ (alternative hypothesis) was accepted which means that there was at least a pair of equal treatments. So it can be concluded that there was interaction between PjBL and learner autonomy on students' speaking skills. So the hypothesis which stated that there is an interaction effect between PjBL and learner autonomy toward speaking skills was proven.

3. There is different in speaking skills between the students with high learner autonomy taught by using PjBL and those who were taught by using conventional teaching method.

Table 4. Difference in speaking skills between A1B1 and A2B1

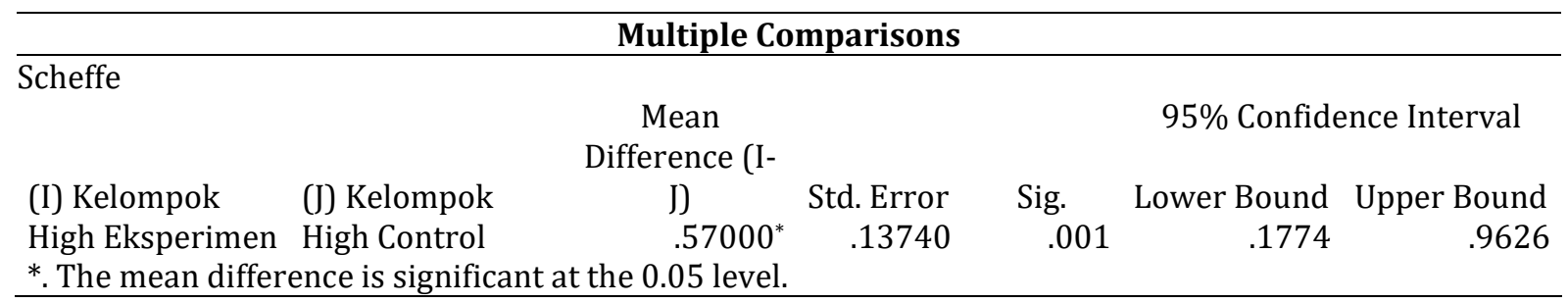

Based on the results of the One way Anova with t- Scheffe (table 4), it can be seen that the group A1B1 and A2B1 were different. The mean difference was 0.57000 with the significant value was 0.001 $(\mathrm{p}<0.05)$. Therefore, it can be concluded that $\mathrm{H} 0$ was rejected and H1 was accepted. So the hypothesis 
states that there was different in speaking skills between the students with high learner autonomy taught by using PjBL and those who were taught by using conventional teaching method was proven.

4. There is not significantly different in speaking skill between the students with low learner autonomy who are treated by using PjBL and those who are taught by using conventional learning method.

Table 5. The of A1B2 and A2B2

\begin{tabular}{|c|c|c|c|c|c|c|}
\hline \multicolumn{7}{|c|}{ Multiple Comparisons } \\
\hline Scheffe & & & & & & \\
\hline (I) Kelompok & $\begin{array}{l}\text { (J) } \\
\text { Kelompok }\end{array}$ & $\begin{array}{c}\text { Mean Difference } \\
(\mathrm{I}-\mathrm{I})\end{array}$ & Std. Error & & $\begin{array}{l}95 \% \text { Confid } \\
\text { Lower Bound }\end{array}$ & $\begin{array}{l}\text { nce Interval } \\
\text { Upper Bound }\end{array}$ \\
\hline $\begin{array}{l}\text { Low Eksperimen } \\
* \text {. The mean diffe }\end{array}$ & $\begin{array}{l}\text { Low Control } \\
\text { ence is signific }\end{array}$ & $\begin{array}{r}.10238 \\
\text { at the } 0.05 \text { level. }\end{array}$ & .13740 & .906 & .2902 & .4950 \\
\hline
\end{tabular}

Based on the results of the One Way Anova with t-Scheffe (table 5), it can be concluded that there is not significantly different in speaking skills between students in group A1B2 compared to students in group A2B2 with mean difference was 0.10238 with significant value 0.906 which was higher than 0.05 (p>0.05). Thus, the H0 was accepted while $\mathrm{H} 1$ was rejected. Therefore, there was not significantly different in speaking skills between students with low learner autonomy who were taught by using PjBL (A1B2) and those who were taught by using conventional learning method (A2B2).

The study finds out that PjBL affects the students' speaking skills better than conventional method which can be seen that the significance value (Sig.) was 0.000 which was smaller than the value 0.05 (F= 18.391 and $\mathrm{p}<0.05)$. PjBL affected the students' speaking skills in the process of teaching and learning. The process was when the students got feedback from the teacher by responding provocative questions to discuss the story on the video about fable, then they could explore and gather some information about the video. Afterward, the students were given a chance by the teacher to conclude and share orally the information that they have been gotten from the video. By those activities, the students were expected to be active in the class and be confident when arguing something or giving comment and information related to the topic of the learning material.

This present research found that PjBL and learner autonomy has a relationship in order to improve students' competency, especially on speaking skills. The study was done by Myartawan (2015) entitled the correlation between learner autonomy and English proficiency of Indonesia EFL college learners. It had a result that learner autonomy and English proficiency as defined in the study had a significant, strong, positive relationship. The study, which was done by Ahmadzadeh (2014) entitled Learner Autonomy in Practice had result students tendency to a well-planned combination of communicative and noncommunicative activities that will enhance both effective teaching and learning at different fields. From the result of data analysis, it could be seen that the learner autonomy had an important role in increasing student's competency.

According to Little John (1997) as cited in Jamila (2013) learner autonomy has some characteristics which are obviously learner-centered. It gave importance to a learner's self. Learning became an accomplishment in the autonomous learner. Teachers became friends to the learners and this state made learning easier and at the same time, peers also get importance as they assess learning. Smith (2005) stated that the practice of project-based, learner-centered teaching and learning, the most fundamental principle of which was the fostering of individual autonomy. By the finding of this study, it can be proven as the students who have high learner autonomy are able to get a higher score by speaking rather than the students who have low learner autonomy. Meanwhile, the students who have high and low learner autonomy in a conventional teaching method group of students got a lower score than the students who were taught by using PjBL. It means that PjBL is important to improve learner autonomy.

\section{Conclussion}

The findings of this study show that there is significant different effect between the students who were taught by using project-based learning and those who were taught by using conventional strategy in which the mean score was 3.83 that was higher than students who were taught by using conventional strategy with mean score $3.49(\mathrm{~F}=18.391$ and $\mathrm{p}<0.05)$. Besides, there was also interaction between project-based learning and learner autonomy with the mean square $16.994(\mathrm{~F}=45.325$ and $\mathrm{p}<0.05)$. There was significant different in speaking skills between the students with high learner autonomy taught by using project-based learning (A1B1) and those who were taught by using conventional strategy (A2B1) in 
which the mean score of A1B1 was 4.20 which was higher than group A2B1 (3.63). The mean difference of the groups was 0.57000 with the significant value was $0.001(p<0.05)$. However, there was not significantly different in speaking skills between students in group A1B2 compared to students in group A2B2 with mean difference was 0.10238 with significant value 0.906 which was higher than 0.05 $(\mathrm{p}>0.05)$.

\section{Reference}

Ahmadzadeh, R. (2014). Learner autonomy in practice, (October), 49-57. Retrieved from http://www.ijonte.org/FileUpload/ks63207/File/05.ahmadzadeh.pdf

Artini, L.P (2017). Project Based Learning Activities and EFL Students' Productive Skills in English. Ganesha University. $\quad$ DIO: http://dx.doi.org/10.17507/jltr.0806.16 Retrieved from http://www.academypublication.com/ojs/index.php/jltr/article/view/jltr080611471155/1282

Bell, S. (2010). Project-Based Learning for the $21^{\text {st }}$ Century: Skills for the Future. Routledge: Taylor\&Francis Group. DOI: 10.1080/00098650903505415. Retrieved from https://www.academia.edu/34971404/

Brown, H. D. (2004). Language Assessment: Principles and Classroom Practices. New York Pearson Education Inc.

Chiang, C. L., \& Lee, H. (2016). The Effect of Project-Based Learning on Learning Motivation and ProblemSolving Ability of Vocational High School Students, 6(9). Retrieved from https://doi.org/10.7763/IJIET.2016.V6.779

Clark H., M., \& Clark. E., V. (1977). Psychology and Language: An Introduction to Psycholinguistics. New York: Harcout Brace Jovanovich.

Cohen,L., Manion, L., Morrison, K. (2007) Research Method in Education. Sixth Edition. Routledge: Taylor \& Francis e-Library

Heriansyah, H. (2012). Speaking Problems Faced by the English Departement Students of Syiah Kuala University. Aceh: Syiah Kuala University.

Ismuwardani, Z., Nuryatin, A., Doyin. (2018). Implementation of Project Based Learning Model to Increased Creativity and Self-Reliance of Students on Poetry Writing Skills. Retrieved from https://doi.org/10.15294/ipe.v8i1.25229

Jamila, M. (2013). Use of Learner Autonomy in Teaching Speaking by Tertiary Level English Language Teachers in Private Universities of Bangladesh, 18(4), 29-43. Retrieved from https://pdfs.semanticscholar.org/8b88/18e647e8b53419243b9412ff079389f2a199.pdf

Larmer, J., Mergendoller, J., Boss, S. (2015). Setting the Standard for Project Based Learning. Buck Institute for Education: USA

Little, D. (1995). Learning As Dialogue: The Dependence Of Learner Autonomy On Teacher Autonomy. Retrieved from https://www.sciencedirect.com/science/article/pii/0346251X95000066

Myartawan, I. P. N. W. (2015). The Correlation Between Learner Autonomy And English Proficiency Of Indonesian Efl College Learners The Correlation Between Learner Autonomy And English Proficiency of Indonesian Efl College Learners (September). Retrieved from http://www.journal.teflin.org/index.php/journal/article/viewFile/155/144

Pratiwi, N. (2016). Project Based Learning to enhance Junior High School Studemts' Speaking Skill and Their Motivation in Learning the Speaking Skill. Retrieved from https://repository.usd.ac.id/5963/2/126332002_full.pdf 
Pratiwi, N. (2015). Analysis of English Book for SMP by Using Revised Bloom Taxonomy. Jakarta: English Education Faculty of Tarbiyahand Teachers Training State Islamic University

Richards, J. C. (2008). Teaching Listening and Speaking From Theory to Practice. Cambridge University Press

Rochmahwati, P. (2015). Project Based Learning to Raise students' Speaking ability, (c). Retrieved from https://pdfs.semanticscholar.org/4f29/718f88a53ad95c455f5a41069a7ca41ded7e.pdf

Smith, M. A. (2005). Autonomy and project-based language learning:, (December). Retrieved from http://citeseerx.ist.psu.edu/

Ur, P. (1996). A Course in Languge teaching. Cambridge: University Press.

Yuliani, Y., \& Lengkanawati, N., S. (2017). Project Based Learning in Promoting Learner Autonomy in an EFL Classroom. Universitas Pendidikan Indonesia. Retrieved from https://www.researchgate.net/publication/320133548_Projectbased_learning_in_promoting_learner_autonomy_in_an_EFL_classroom

Zhang, S. (2009). The Role of input, interaction, and output in the development of oral fluency. English Language Teaching. 